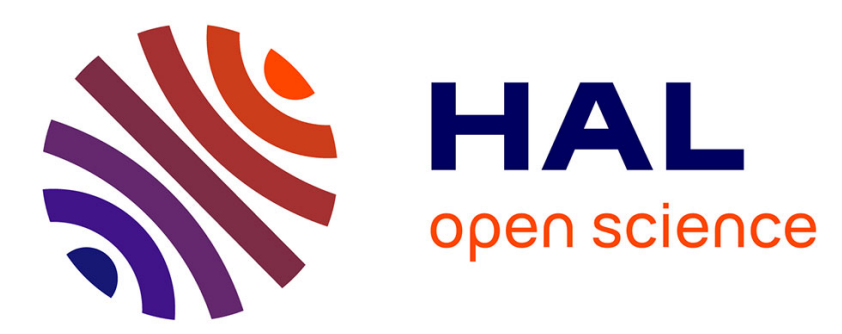

\title{
Identification of synthetic dyes in early colour photographs using capillary electrophoresis and electrospray ionisation-mass spectrometry
}

Ana Maria López-Montes, Anne-Laurence Dupont, Bernard Desmazières, Bertrand Lavédrine

\section{To cite this version:}

Ana Maria López-Montes, Anne-Laurence Dupont, Bernard Desmazières, Bertrand Lavédrine. Identification of synthetic dyes in early colour photographs using capillary electrophoresis and electrospray ionisation-mass spectrometry. Talanta, 2013, 114, pp.217 - 226. 10.1016/j.talanta.2013.04.020 . hal01491084

\section{HAL Id: hal-01491084 \\ https://hal.science/hal-01491084}

Submitted on 22 Mar 2017

HAL is a multi-disciplinary open access archive for the deposit and dissemination of scientific research documents, whether they are published or not. The documents may come from teaching and research institutions in France or abroad, or from public or private research centers.
L'archive ouverte pluridisciplinaire $\mathbf{H A L}$, est destinée au dépôt et à la diffusion de documents scientifiques de niveau recherche, publiés ou non, émanant des établissements d'enseignement et de recherche français ou étrangers, des laboratoires publics ou privés. 


\title{
Identification of synthetic dyes in early colour photographs using capillary electrophoresis and electrospray ionisation- mass spectrometry
}

\author{
Ana $\mathrm{M}^{\mathrm{a}}$ López-Montes $^{\mathrm{a}, \mathrm{b}}$, Anne-Laurence Dupont ${ }^{\mathrm{a}, *}$, Bernard Desmazières ${ }^{\mathrm{c}}$, \\ Bertrand Lavédrine $^{\mathrm{a}}$ \\ ${ }^{a}$ Centre de recherche sur la conservation des collections, Muséum National d'Histoire Naturelle, CNRS USR 3224,36 rue Geoffroy-Saint-Hilaire, F-75005, \\ Paris, France \\ ${ }^{\mathrm{b}}$ Department of Painting, Faculty of Fine Arts, University of Granada, Avda. Andalucía s/n, ES-18071 Granada, Spain \\ ' Global Bioénergies, 5 rue Henri Desbruères, F-91030 Evry Cedex, France
}

\section{A R T I C L E I N F O}

\section{Article history:}

Received 3 October 2012

Received in revised form

29 March 2013

Accepted 8 April 2013

Available online 17 April 2013

Keywords:

Autochrome

Capillary electrophoresis

Electrospray ionisation-mass spectrometry

Synthetic dyes

Cultural heritage

\begin{abstract}
A B S T R A C T
Capillary electrophoresis with photodiode array detection (CE-PDA) and with electrospray ionisation-mass spectrometry (CE-ESI-MS) was used for the separation and the identification of 23 synthetic organic dyes, among those used in early 20th century colour photographs such as autochromes. Both cationic and anionic dyes could be separated within 15 min using a single CE-PDA method. The method was used as the basis to develop a CE-ESI-MS methodology through the optimisation of the relevant ESI and MS parameters. Sheath liquid composition, nebulising gas pressure, drying gas flow rate and drying gas temperature were found to influence the sensitivity of the detection. These parameters were optimised in positive and negative ion modes for cationic dyes and anionic dyes, respectively. The two analyses could be carried out successively on a single sample. In view of the application to cultural heritage objects, the CE-ESI-MS analytical procedure was applied to identify the dyes in a Filmcolor artefact, late version of the autochrome. The results complemented and enhanced current knowledge as four cationic dyes and three anionic dyes were identified. Four additional dyes are proposed as possibly present as traces.
\end{abstract}

(c) 2013 Elsevier B.V. All rights reserved.

\section{Introduction}

For the past thirty years, the interest for the preservation of photographic materials has intensified [1]. The knowledge of the structure and composition of these artefacts is essential to design appropriate approaches for their preservation and conservation [2]. The autochrome is an early colour photograph process on glass, based on additive colour mixing theory, which uses three coloured lights to produce a full colour gamut. The first colour photographic process based on this principle was produced in 1894 [3]. The autochrome was patented in 1903 by the Lumière brothers and was introduced commercially in 1907. The autochrome Lumière was among the first industrially produced colour photograph which was easy to use and presented delicate colour rendering.

The process encountered an enormous success among professionals and amateurs alike, and thousands of autochromes are now preserved in art collections such as at the National Geographic Society in Washington (USA) and the Albert Kahn museum in Boulogne (France).

\footnotetext{
* Corresponding author. Tel.: +331 4079 5307; fax: +33140795312.

E-mail address: aldupont@mnhn.fr (A.-L. Dupont).
}

In replacement of the glass plate, a film based photograph called Filmcolor was launched in 1931 albeit it was short-lived, as Kodak and Agfa began to produce multi-layer subtractive colour films.

An autochrome consists of a colour mosaic of microscopic granules $(10 \mu \mathrm{m}$ to $15 \mu \mathrm{m}$ in diameter) made of potato starch, coloured with the three primary colours red-orange, blue-violet and green using synthetic dyes, and mixed together. The structure and composition of an autochrome is represented in Fig. 1.

A glass plate was spread with a sticky varnish layer made of the resin portion of dammar. It was then powdered with the dyed starch to create a colour mosaic. Then, lampblack powder was applied to fill the void spaces. The starch grains were flattened by applying pressure (around $5000 \mathrm{~kg} \mathrm{~cm}^{-2}$ ) to limit the light diffusion and increase the transparency of the layer. A second varnish layer made of dammar, castor oil and cellulose nitrate was applied to protect the colour mosaic and finally, the plate was covered with a lightsensitive emulsion (panchromatic silver bromide). A final varnish layer was applied, which composition was a recipe of each photographer [2]. The autochrome plate was placed into the camera with the glass side nearest the lens. When the photograph was taken, the light came through the lens and the glass backing of the plate, and was filtered by the coloured starch mosaic before reaching the photographic sensitive emulsion 


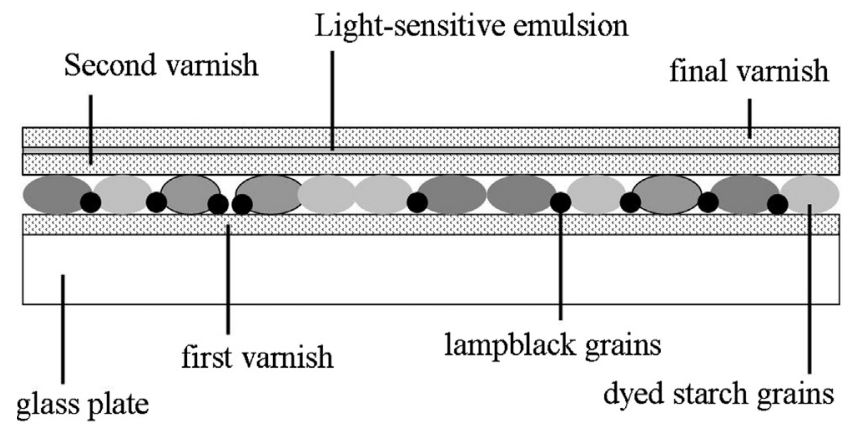

Fig. 1. Structure and composition of an autochrome plate.

[4,5]. After chemical processing, the image could be viewed directly in transmitted light or projected like a slide. The Filmcolor photograph studied in this article, which was produced in 1950-1951, presents the same layer structure and composition.

Little information was published about the dyes used in autochromes at the time of their production because the process remained proprietary. In 1939, Seyewetz, a chemist who worked with the Lumière brothers, revealed some of these dyes [6]. Recently, additional information was compiled by Lavédrine and Gandolfo [3] based on their research of the Lumière archives. All the colourants mentioned in these documents are synthetic dyes.

Synthetic dyes are used for very different applications, in pharmaceutical, textile, cosmetic, and food industries, and especially in graphic documents and fine art in the 19th and 20th century. Various analytical techniques have been developed for their characterisation, but capillary electrophoresis (CE) is perhaps the best alternative due to the many advantages it offers over other separation techniques. CE provides high separation efficiency, selectivity and resolution power combined with short analysis time, simple sample preparation (no derivatisation), little solvent consumption and extraordinarily small sample volume. Indeed, a major requirement for conservators, conservation scientists, archaeologists and art historians is sample miniaturisation in order to observe the physical integrity of the cultural heritage artefacts under study. However, one should also mention the corollary disadvantages, as for example the low sample load-ability (nL range) and the small UV light path length of the detector cell in the case of the photodiode array (PDA), the latter being sometimes circumvented with the use of special detection setups such as bubble cells. Methods based on CE with various detection systems for the identification of synthetic dyes have been proposed. Variable wavelength UV and PDA are by far the most commonly used for food [7-17], textiles [18,19] and pen inks dyes [20,21]. A few accounts can be found on laser-induced fluorescence detection (LIF) for food dyes [22], as well as electrochemical detection (ED) [23] and mass spectrometry (CE-MS) for textile dyes [24,25]. The characterisation of dyes in early colour photographs has rarely been studied to the exception of Lavédrine's work in 1992 [26].

The aim of the present research was to develop a methodology primarily for the identification of synthetic dyes used in early colour photographs, but that could also be applicable to other cultural heritage materials such as textile, paper and modern photographs, while minimising sampling. A single method was developed using CE-PDA as a screening technique in order to appraise the separation and identification of the largest possible number of cationic and anionic dyes among those used for autochromes. The optimisation of the separation conditions was used to develop a more dedicated methodology using CE coupled with electrospray ionisation-mass spectrometry detection (CE-ESI-MS). The hyphenation with MS allows for a much greater performance than PDA as even when the peaks are not fully resolved on the total ion electropherogram (TIE), the identification of the dyes can be made using the mass over charge ratio $(\mathrm{m} / \mathrm{z})$ of the ions produced.

\section{Experimental}

\subsection{Materials}

The following chemicals were used: ethanol (absolute, > 99\%, Merck), methanol (HPLC grade, >99.99\%, Fischer), 2-propanol (99.5\%, Sigma-Aldrich), acetonitrile (LiChrosolv, > 99.9\%, Merck), sodium hydroxide ( $1 \mathrm{~N}$, Merck). Formic acid ( $\geq 98 \%$ ), acetic acid ( $\geq 99.5 \%$ ), ammonium carbonate $\left(\geq 30 \% \mathrm{NH}_{3}\right)$ and ammonium acetate $(98 \%)$ were from Sigma-Aldrich. Water was Milli-Q plus (Millipore, Bedford, MA, USA).

Synthetic dyes can be cationic, anionic or non-ionic, but only those pertaining to the two first types were used as reference samples. They were chosen based on existing information on autochromes dyes [3,6]. Whenever available, the dye content is indicated in parenthesis. Their abbreviations, used onward for convenience, as well as their natural charge are marked in parenthesis. They were: Methylene Blue $(\mathrm{MB},+)$ (C.I. 52015) and Crystal Violet (CV, +) (C.I. 42555) from R.A.L. (Martillac, France); Erythrosine B (ERB, -) (C.I. 45430) from Certistain-Merck (Darmstadt, Germany); Patent blue VF (PBVF, -) (C.I. 42045), Eosin Y (EY, -) (C.I. 45380), Eosin B ( 95\%, EB, -) (C.I. 45400), Brillant Green $(\mathrm{BG},+)$ (C.I. 42040), Auramine O ( 80\%, AO, +) (C.I. 41000), Chrysoidine $\mathrm{G}(\mathrm{CG},+)$ (C.I. 11270), Ethyl Violet $(\mathrm{EV},+)$ (C.I. 42600), Rhodamine B (RHB, +) (C.I. 45170), Rhodamine 6 G (RH6G, +) (C.I. 45160), Thioflavin $\mathrm{T}(\mathrm{TT},+)$ (C.I. 49005), Chrysophenine ( 65\%, CH, -) (C.I. 42895), Diiodofluorescein (DII, -) (C.I. 45425:1) and Rose Bengal (RB, -) (C.I. 45440) from Aldrich (St. Quentin Fallavier, France); Patent Blue V (calcium salt) (PBV, -) (C.I. 42051) from Fluka (St. Quentin Fallavier, France); Basonyl Blue (BB, +) (C.I. 42563) and Flexo Blue $810(\mathrm{FB},+)(\mathrm{C}$. I. 42025) from BASF; Victoria Blue R ( 80\%, VBR, +) (C.I. 44040) and Erythrosine B:2 (ERB2, -) (C.I. 45430:2) from Sigma (St. Quentin Fallavier, France); Auramine G (AG, +) (C.I. 41005) from Gurr Microscopy Materials (Poole, UK). Victoria Blue B (VBB, +) (C.I. 44045) was provided from in-house MNHN. Chemical structures are represented in figure Fig. 2.

\subsection{Sample preparation}

Work solutions of reference dyes were prepared by dissolving $0.5 \mathrm{mg}$ of dye powder in $10 \mathrm{~mL}$ of water, methanol or water: methanol (1:1).

Sampling on the Filmcolor artefact was carried out as follows. Ten square millimetres of the surface containing the dyed starch layer and upper varnish layers were scratched using a scalpel, and transferred in $3 \mathrm{~mL}$ ethyl acetate in order to solubilise the varnish. After $10 \mathrm{~min}$ the mixture was filtered (PTFE, $0.45 \mu \mathrm{m}$ pores) using a membrane filter and filter holder. Once dry, the filter, which had retained the dyes particles, was introduced in methanol:water (1:1) (50:50) and heated during $30 \mathrm{~min}$ at $70{ }^{\circ} \mathrm{C}$ in a heating block unit (Pierce). After removing the filter the solution was centrifuged at $9000 \mathrm{rpm}$ during $3 \mathrm{~min}$ and evaporated to dryness. The mass of dyes recovered after this purification step was estimated to $0.5 \mu \mathrm{g}$ at most. Finally, the dry residue was dissolved in $25 \mu \mathrm{L}$ of water: methanol (1:1).

\subsection{Analytical procedures}

\subsubsection{UV-visible spectroscopy}

A Unicam UV/Visible spectrometer UV 2 was used across the range $190-700 \mathrm{~nm}$. The system operation and data acquisition were performed using the software VISION pro. The UV-vis spectra allowed selecting the most appropriate solvent for each dye and the specific detection wavelengths for the CE separation. The dye concentrations were adjusted to provide non-saturated absorption maxima. 


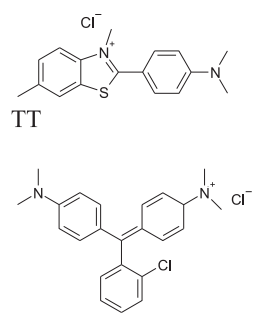

FB
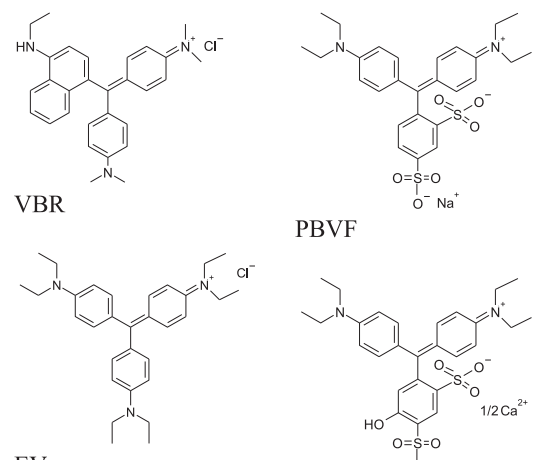

PBVF

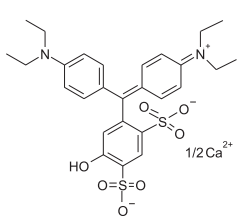

$\mathrm{AO}$

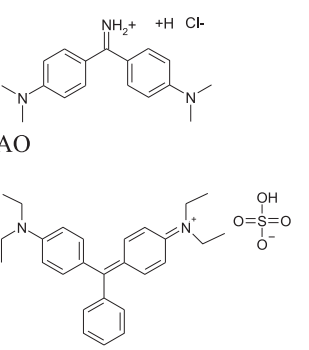

BG

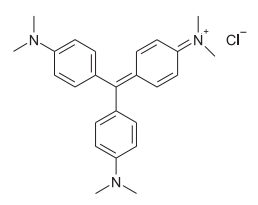

CV

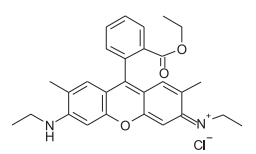

RH6G

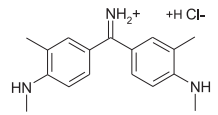

AG

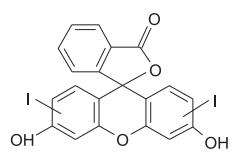

DII

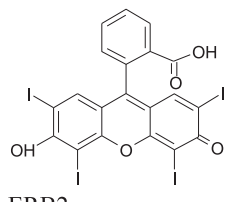

ERB2

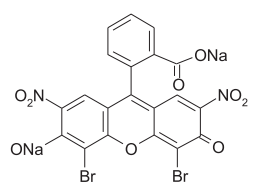

EB

Fig. 2. Chemical structures of the synthetic dyes.

\subsection{2. $C E$}

Electrophoretic separations were performed with a P/ACE MDQ (Beckman Coulter) equipped with a PDA detector $(200-590 \mathrm{~nm})$ (Beckman Coulter). The software 32 Karat (Beckman Coulter) version 5.0 was used for data acquisition and processing.
Separations were carried out using a fused-silica capillary of $50 \mu \mathrm{m}$ internal diameter, which was cut to a length of $60 \mathrm{~cm}$ (50 $\mathrm{cm}$ effective length to the detector window) for CE-PDA and $62 \mathrm{~cm}$ for CE-ESI-MS. Between analyses, the capillary was washed with $\mathrm{NaOH} 0.1 \mathrm{M}$ (3 min) and deionised water (1 min), followed by the electrolyte ( $3 \mathrm{~min}$ ). After each analysis, the capillary was rinsed with deionised water $(2 \mathrm{~min})$. The electrolyte was changed between series of three runs.

The electrolyte consisted of $50 \mathrm{mM}$ ammonium acetate with $15 \%$ (v/v) acetonitrile, and was adjusted to $\mathrm{pH} 9$ with $\mathrm{NaOH} 1 \mathrm{M}$. It was filtered through a $0.22 \mu \mathrm{m}$ pores PTFE syringe filter prior to use. The separation was performed at $20^{\circ} \mathrm{C}$. The applied voltage was $20 \mathrm{kV}$, resulting in a current of $63 \mu \mathrm{A}$. The injection was made in hydrodynamic mode at 1 psi for $4 \mathrm{~s}$. Analysis time was 20 min.

The detection wavelength of each dye was selected according to the UV-vis features. Peak identification was done using migration times $\left(t_{\mathrm{m}}\right)$ and UV spectra. BG was injected at the beginning of each working day in order to check for day-to-day variations. Triplicate samples were prepared and triplicate analyses of each sample were carried out (relative standard deviations corresponding to interday and intraday variations-RSD-is calculated on $n=9$ ).

\subsubsection{ESI-ITMS}

A mass spectrometer with an ion trap analyser (ITMS) equipped with an electrospray ionisation (ESI) source (HCTUltra, Bruker Daltonics) was used. The pumping system is composed of a rough pump and two turbomolecular pumps. Fore vacuum was 4.1-4.2 mbars and high vacuum was $9 \times 10^{-6}$ mbars. The detection mass range is $\mathrm{m} / \mathrm{z} \mathrm{50-3000} \mathrm{amu}$ (standard mode). The mass calibration was carried out once at the beginning of the work, both in positive and in negative ion modes, over the entire mass range using seven standard compounds (ESI tune mix, Bruker). The software Compass 1.3 for Esquire/HCT was used for data acquisition and analysis. CE-MS coupling was carried out using a sheath liquid coaxial ESI interface (Agilent Technologies).

The following MS parameters were used: a capillary voltage of $4000 \mathrm{~V}$ (capillary exit voltage of $121 \mathrm{~V}$ ), end plate offset of $-500 \mathrm{~V}$ and skimmer voltage of $40 \mathrm{~V}$. The maximum accumulation time was $50.00 \mathrm{~ms}$ and the 'smart target' (maximum number of ions in the trap) was set to 5000. The optimal protruding length of the CE capillary from the sprayer needle, which is reported to influence the spray performances [27], was between 0.03 and $0.3 \mathrm{~mm}$. The mass spectra were acquired in ultra scan mode (scan speed $26000 \mathrm{~m} / \mathrm{z} \mathrm{s}^{-1}$, resolution 0.4 FWHM (Full-Width at Half-Maximum)/ $\mathrm{m} / \mathrm{z}$ ). Both positive and negative ion modes were used successively upon two consecutive injections of the same sample for cationic dyes and anionic dyes respectively. $\mathrm{MS}^{2}$ was performed in positive ion mode only.

Positive ion mode was used over the scan range from $200 \mathrm{~m} / \mathrm{z}$ to $800 \mathrm{~m} / \mathrm{z}$ with a target mass set to $\mathrm{m} / \mathrm{z} 400$. The sheath liquid consisted of methanol/water (1:1) with $0.5 \%(\mathrm{v} / \mathrm{v})$ of formic acid, and was dispensed with a syringe pump at a flow-rate of $400 \mu \mathrm{L} \mathrm{h}^{-1}$. The nebulising gas $\left(\mathrm{N}_{2}\right)$ pressure was set to $5 \mathrm{psi}$. Drying gas temperature was $300{ }^{\circ} \mathrm{C}$ and flow-rate was $4 \mathrm{~L} \mathrm{~min}^{-1}$.

Negative ion mode was used over the scan range from $200 \mathrm{~m} / \mathrm{z}$ to $1400 \mathrm{~m} / \mathrm{z}$ with a target mass set to $\mathrm{m} / \mathrm{z} 800$. The sheath liquid was 2-propanol/water (1:1) and its flow-rate was $400 \mu \mathrm{L} \mathrm{h}^{-1}$. The nebulising gas pressure was set to 7 psi. Drying gas temperature was $300{ }^{\circ} \mathrm{C}$ and flow-rate was $4 \mathrm{~L} \mathrm{~min}^{-1}$.

Signal intensity, peak area and height, signal to noise ratio $(S)$ $N^{\prime}$ ) and resolution were observed as basis for the optimisation of the sensitivity of the detection. The optimisation was carried out with separate single injections of each dye. Precision was evaluated with the RSD calculated on $t_{\mathrm{m}}$. 


\section{Results and discussion}

\section{1. $U V-v i s$}

The wavelengths selected for detection in CE-PDA were the absorption maxima $\left(\lambda_{\max }\right)$ of each dye, except for the group of blue-violet dyes as their $\lambda_{\max }$ was around $600-700 \mathrm{~nm}$, which is outside the PDA range. The second absorption region, around 250$350 \mathrm{~nm}$, was thus used. Table 1 shows the $\lambda_{\max }$ of each dye. The detection wavelength used is marked in bold.

\subsection{Optimisation of the CE-PDA method}

To this date, CE methods proposed in the literature have been developed for the identification of either cationic or anionic dyes. In a first screening method a simultaneous identification of a large number of both types of dyes seemed an important goal to reach, mostly, as explained earlier, regarding the sampling constraints related to the targeted application to cultural heritage objects.

The optimisation was carried out with six cationic dyes (TT, CG, BG, CV, RHB, RH6G) and eight anionic dyes (CH, RB, DII, EB, EY, $\mathrm{ERB}, \mathrm{ERB} 2, \mathrm{PBV})$ dissolved in water:methanol (1:1). Each experimental and instrumental variable were investigated separately and each dye was examined individually.

\subsubsection{Electrolyte}

The electrolyte was chosen among those compatible with an IT mass analyser, in view of the use of CE-ESI-MS. Based on published work where a non-aqueous electrolyte for the identification of synthetic dyes was used [22], ammonium acetate dissolved in several organic solvents (methanol, acetonitrile, ethanol, 2-propanol and acetonitrile:methanol) was tested at different concentrations (ranging from $10 \mathrm{mM}$ to $60 \mathrm{mM}$ ). Also, the addition of acetic acid and formic acid was tested up to $20 \%$ $(\mathrm{v} / \mathrm{v})$. A good separation of the cationic dyes was achieved with $55 \mathrm{mM}$ ammonium acetate and $5 \%(\mathrm{v} / \mathrm{v})$ acetic acid in methanol, but none of the conditions tested were suitable for the separation of the anionic dyes. Another electrolyte had thus to be found.

Based on published results [28,29], ammonium acetate in water was tested at $\mathrm{pH} 9$ at 20, 50 and $70 \mathrm{mM}$. High ionic strength leading to slower electroosmotic flow (EOF), $70 \mathrm{mM}$ increased the analysis time up to $13 \mathrm{~min}$ for the six dyes tested and additionally raised the current to $125 \mu \mathrm{A}$, which generates Joule heating. Moreover, as ESI is prone to analyte signal suppression by high buffer concentrations, the latter was avoided in view of the future use of CE-ESI-MS [30]. Conversely, $20 \mathrm{mM}$ led to poor peaks shape and poor resolutions. The concentration of $50 \mathrm{mM}$ provided the best compromise between resolution and analysis time while a reasonable current around $60 \mu \mathrm{A}$ was achieved.

The effect of $\mathrm{pH}$ was investigated in the range 7-11 in one unit steps and a pH 9 allowed a good compromise between resolution and analysis time for the cationic and anionic dyes.

Methanol, ethanol and acetonitrile (5\%, 15\% and 30\%,v/v) were tested as organic modifiers in the electrolyte. The electrophoretic migration is affected by the addition of solvent due to the change in viscosity, size of the dissolved analytes and protonation equilibria ( $\mathrm{pKa}$ values), as well as the interaction between analytes and background electrolyte additives [31]. Acetonitrile at $15 \%(\mathrm{v} / \mathrm{v})$ shortened the analysis time to 16 min for the fourteen cationic and anionic dyes without loss in resolution compared to the other solvents tested in equivalent percentages (for which analysis times were up to $23 \mathrm{~min}$ ). Lower percentage of solvent, and no solvent at all, did not provide enough resolution, while $30 \%$ solvent considerably lengthened the analysis. The optimised electrolyte was thus composed of $50 \mathrm{mM}$ ammonium acetate at $\mathrm{pH} 9$ with $15 \%(v / v)$ acetonitrile.

Table 1

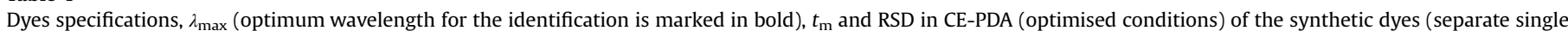

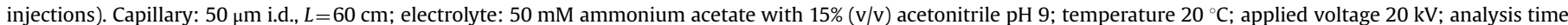
$20 \mathrm{~min}$, hydrodynamic injection at $1 \mathrm{psi}$ for $4 \mathrm{~s}$.

\begin{tabular}{|c|c|c|c|c|c|c|c|c|}
\hline \multirow[t]{2}{*}{ Dye } & \multirow[t]{2}{*}{ Abbrev. } & \multirow[t]{2}{*}{ Colour index } & \multirow[t]{2}{*}{ CAS no. } & \multirow[t]{2}{*}{ Hue } & \multirow[t]{2}{*}{ Solvent } & \multirow[t]{2}{*}{ Max. Absorbance (nm) } & \multicolumn{2}{|c|}{ migration time } \\
\hline & & & & & & & $\min$ & $\operatorname{RSD} \%(n=9)$ \\
\hline \multicolumn{9}{|l|}{ CATIONIC DYES } \\
\hline Thioflavin $\mathrm{T}$ & TT & 49005 & $2390-54-7$ & yellow & $\mathrm{H}_{2} \mathrm{O}$ & $254 ; 412$ & 3.64 & 0.54 \\
\hline Auramine $\mathrm{O}$ & $\mathrm{AO}$ & 41000 & $2465-27-2$ & orange-yellow & $\mathrm{H}_{2} \mathrm{O}$ & $250 ; 370 ; 432$ & 3.78 & 0.52 \\
\hline Auramine G & AG & 41005 & $2151-60-2$ & orange-yellow & $\mathrm{H}_{2} \mathrm{O}$ & $249 ; 370 ; 432$ & 3.79 & 0.52 \\
\hline Flexo Blue 810 & FB & 42025 & $3521-06-0$ & blue-purple & $\mathrm{H}_{2} \mathrm{O}$ & $302 ; 410 ; \mathbf{5 5 9} ; 631$ & 3.96 & 1.51 \\
\hline Crystal Violet & $\mathrm{CV}$ & 42555 & $548-62-9$ & blue-purple & $\mathrm{H}_{2} \mathrm{O}$ & $249 ; 303 ; \mathbf{5 2 2} ; 591$ & 3.96 & 5.05 \\
\hline Brillant Green & BG & 42040 & $633-03-4$ & green & $\mathrm{H}_{2} \mathrm{O}$ & $282 ; 318 ; 426 ; 624$ & 4.01 & 0.99 \\
\hline Rhodamine 6G & RH6G & 45160 & $989-38-8$ & red & $\mathrm{CH}_{3} \mathrm{OH}$ & $246 ; 347 ; \mathbf{5 2 4}$ & 4.07 & 0.49 \\
\hline Victoria Blue R & VBR & 44040 & $2185-86-6$ & blue & $\mathrm{H}_{2} \mathrm{O} / \mathrm{CH}_{3} \mathrm{OH}$ & $214 ; 247 ; \mathbf{5 9 3} ; 611$ & 4.07 & 0.24 \\
\hline Ethyl violet & EV & 42600 & $2390-59-2$ & blue-purple & $\mathrm{H}_{2} \mathrm{O}$ & $250 ; 310 ; \mathbf{5 8 7} ; 600$ & 4.14 & 0.72 \\
\hline Rhodamine B & RHB & 45170 & $81-88-9$ & red-purple & $\mathrm{H}_{2} \mathrm{O}$ & $259 ; 354 ; \mathbf{5 5 0}$ & 5.52 & 9.05 \\
\hline Chrysoidine G & CG & 11270 & $532-82-1$ & orange & $\mathrm{H}_{2} \mathrm{O}$ & $246 ; 278 ; 426$ & 5.56 & 1.79 \\
\hline Basonyl Blue & BB & 42563 & $2185-87-7$ & blue & $\mathrm{CH}_{3} \mathrm{OH}$ & $298 ; 448 ; 593$ & 5.68 & 3.16 \\
\hline Methylene Blue & MB & 52015 & $61-73-4$ & blue & $\mathrm{H}_{2} \mathrm{O} / \mathrm{CH}_{3} \mathrm{OH}$ & $246 ; 297 ; 612 ; 664$ & 5.70 & 1.75 \\
\hline Victoria Blue B & VBB & 44045 & $2580-56-5$ & blue & $\mathrm{CH}_{3} \mathrm{OH}$ & $251 ; \mathbf{5 5 7} ; 614$ & 7.35 & 1.36 \\
\hline \multicolumn{9}{|l|}{ ANIONIC DYES } \\
\hline Patent Blue VF & PBVF & 42045 & $129-17-9$ & blue & $\mathrm{H}_{2} \mathrm{O}$ & $310 ; 409 ; \mathbf{5 5 8} ; 640$ & 7.98 & 1.25 \\
\hline Patent Blue V & PBV & 42051 & $3536-49-0$ & blue & $\mathrm{H}_{2} \mathrm{O}$ & $310 ; 410 ; \mathbf{5 6 5} ; 638$ & 9.16 & 1.09 \\
\hline Chrysophenine & $\mathrm{CH}$ & 24895 & $2870-32-8$ & yellow & $\mathrm{CH}_{3} \mathrm{OH}$ & $251 ; 381$ & 10.40 & 1.92 \\
\hline Rose Bengal & $\mathrm{RB}$ & 45440 & $632-69-9$ & red & $\mathrm{H}_{2} \mathrm{O}$ & $259 ; 550$ & 12.45 & 0.40 \\
\hline Erythrosine B & ERB & 45430 & $568-63-8$ & red & $\mathrm{H}_{2} \mathrm{O}$ & $261 ; 351 ; \mathbf{5 5 0}$ & 12.49 & 0.80 \\
\hline Erythrosine $\mathrm{B}: 2$ & ERB2 & 45430:2 & $15905-32-5$ & red & $\mathrm{CH}_{3} \mathrm{OH}$ & $249 ; 314 ; 524$ & 12.56 & 0.79 \\
\hline Eosin $Y$ & EY & 45380 & $548-26-5$ & red & $\mathrm{H}_{2} \mathrm{O}$ & $254 ; 301 ; 342 ; 515$ & 13.53 & 3.69 \\
\hline Diiodofluorescein & DII & $45425: 1$ & $31395-16-1$ & red & $\mathrm{CH}_{3} \mathrm{OH}$ & $253 ; 302 ; \mathbf{5 0 7}$ & 14.78 & 0.20 \\
\hline Eosin B & EB & 45400 & $548-24-3$ & red & $\mathrm{CH}_{3} \mathrm{OH}$ & $274 ; 516$ & 15.24 & 3.93 \\
\hline
\end{tabular}




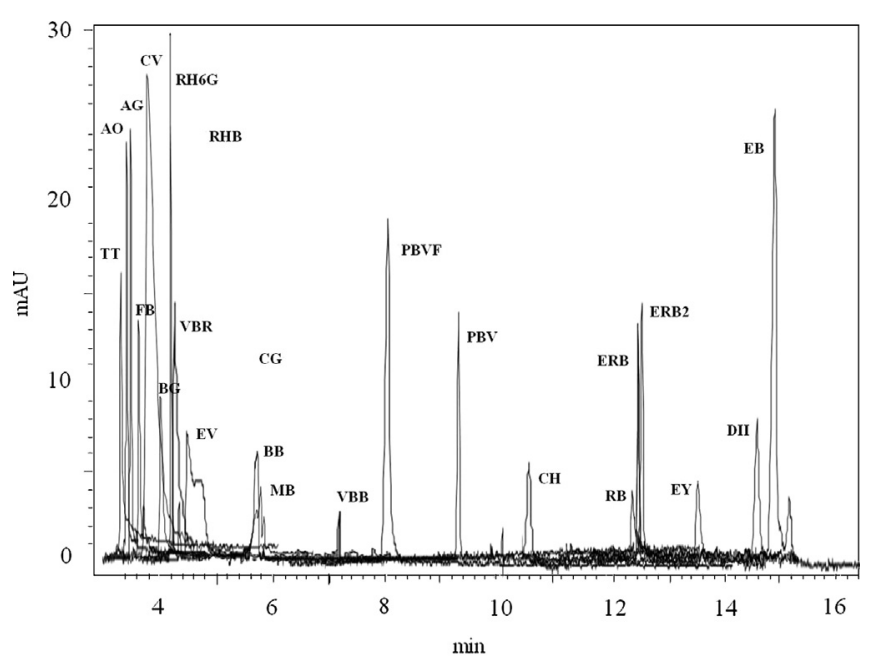

Fig. 3. Electropherograms of the dyes (separate single injections): Capillary: $50 \mu \mathrm{m}$ i.d., $L=60 \mathrm{~cm}$; electrolyte: $50 \mathrm{mM}$ ammonium acetate with $15 \%(\mathrm{v} / \mathrm{v})$ acetonitrile $\mathrm{pH} 9$; temperature $20^{\circ} \mathrm{C}$; applied voltage $20 \mathrm{kV}$; analysis time $20 \mathrm{~min}$, hydrodynamic injection at $1 \mathrm{psi}$ for $4 \mathrm{~s}$, PDA detection.

\subsubsection{Instrumental parameters}

The temperature variation in the range $15-35{ }^{\circ} \mathrm{C}$ showed that above $25{ }^{\circ} \mathrm{C}$ resolution worsened. The temperature selected was $20{ }^{\circ} \mathrm{C}$, mostly for energy saving concerns.

The voltage which allowed obtaining shortest analysis time while maintaining a good resolution was $20 \mathrm{kV}$ (range tested 10 $30 \mathrm{kV}$ ). This resulted in a current of $63 \mu \mathrm{A}$.

Hydrodynamic injection was used for better reproducibility of the sample plug volume since conductivity, which is the basis of the electrokinetic injection, varies widely in samples from real historic artefacts targeted in this study. Injection pressure and time were tested in the range $0.5-3$ psi and 4-12 s. As expected, peak area and peak height increased but resolution decreased with increasing injection pressure and time. A compromise was found with $1 \mathrm{psi}$ and $4 \mathrm{~s}$, which allowed obtaining symmetrical peaks.

The electropherograms obtained for each dye under these optimised conditions are presented in Fig. 3.

Table 1 gathers the migration time (and RSD) of each dye injected separately. All the dyes could be discriminated based on their $t_{\mathrm{m}}$ and $\mathrm{UV}$ absorption features. For instance, even though RB and ERB migrated consecutively very closely and were both detected at $550 \mathrm{~nm}$, they could be distinguished using their full UV spectra: RB presents two $\lambda_{\max }(259 \mathrm{~nm}$ and $550 \mathrm{~nm})$ and ERB has three $\lambda_{\max }(261 \mathrm{~nm}, 351 \mathrm{~nm}$ and $550 \mathrm{~nm})$.

The separation was quite fast, with $t_{\mathrm{m}}$ of the cationic dyes ranging between $3.64 \mathrm{~min}$ (TT) and $5.56 \mathrm{~min}$ (CG), and $t_{\mathrm{m}}$ for the anionic dyes, ranging from $7.98 \mathrm{~min}$ (PBVF) to $15.24 \mathrm{~min}$ (EB).

\subsection{Optimisation of the CE-ESI-MS methodology}

Positive ion mode detection is most often used in ESI-MS several factors make negative ion ESI more challenging, one being the difficulty to produce stable, negative ions to carry the excess negative charge at low analyte concentrations [32].

Anionic dyes did not yield a remarkable signal in positive ion mode and negative ion mode had to be used. Therefore both modes were used alternatively on the same sample.

Comparing Figs. 3 and 4, it appears that the migration times are occasionally different in CE-PDA and CE-ESI-MS. The small difference in capillary length can be one explanation, but the main reason reported in the literature to modify migration time in CE-ESI-MS is the suction effect which, in the coaxial ESI configuration, stems from the nebulising gas and the drying gas, as well as from the CE capillary a

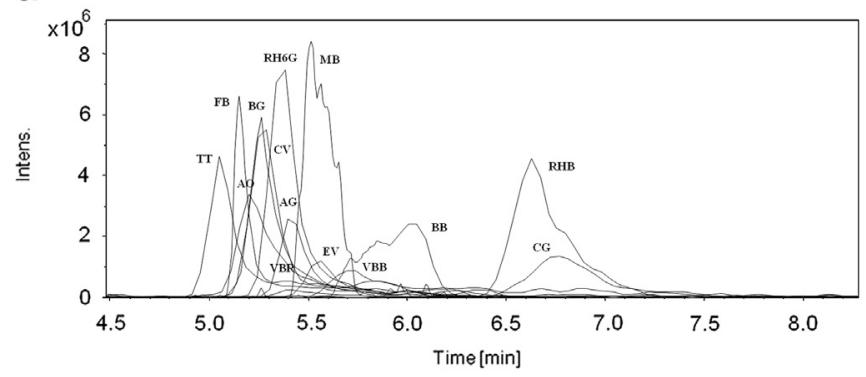

b

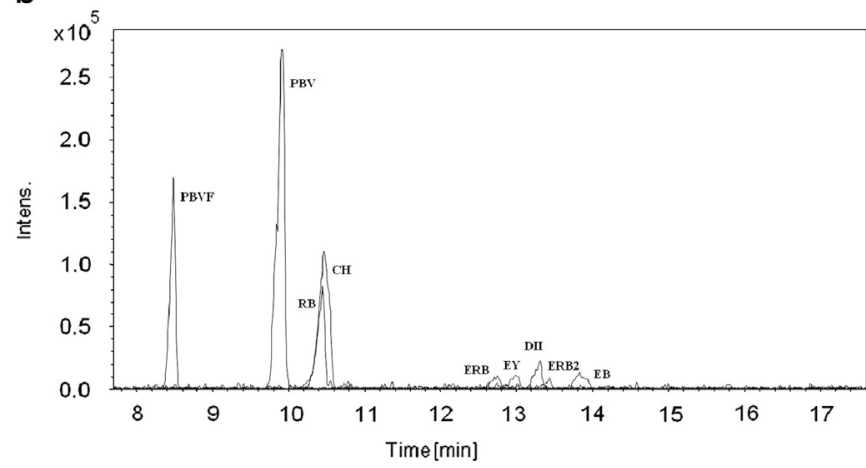

Fig. 4. Superimposed EIEs of the cationic dyes (a) and the anionic dyes and (b) (single injections).

protrusion length from the interface needle [27]. However suction effect would normally not affect the migration order as observed on the figures for some of the cationic dyes (e.g. FB and AO). In that respect, it has to be pointed out that this inversion in $t_{\mathrm{m}}$ may be only apparent as with migration times within tenth of seconds and considering the RSD, small variations among repeat analyses would explain an occasional variability on $t_{\mathrm{m}}$. Indeed superimposed single electropherograms chosen among those obtained from several injections are represented on the figures.

\subsubsection{CE-ESI-MS(+) for cationic dyes}

From the three organic solvents tested (methanol, ethanol and 2-propanol) with water (1:1) as sheath liquid, methanol provided the best sensitivity. As for its proportion, signal intensity was best with $\mathrm{MeOH}: \mathrm{H}_{2} \mathrm{O}$ 1:1 (range tested: 1:3, 1:1 and 3:1). Formic acid at $0.5 \%$ $(\mathrm{v} / \mathrm{v})$ was preferred over acetic acid to improve ionisation (increased signal intensity) as the sensitivity resulted somewhat better (range tested: 0.25 to $1.25 \%, \mathrm{v} / \mathrm{v}$ ). A sheath liquid flow rate of $400 \mu \mathrm{L} \mathrm{h}^{-1}$ was sufficient to obtain a good spray, a stable MS capillary current and considerable sensitivity (range tested: $100 \mu \mathrm{L} \mathrm{h}^{-1}$ to $600 \mu \mathrm{L} \mathrm{h}^{-1}$ ).

The effect of the pressure of the nebulising gas was examined in the range of 5 psi to 11 psi. The increase of the pressure produced a reduction in the migration times but a decrease in sensitivity. The lowest pressure of 5 psi was chosen.

The drying gas flow rate was tested between $2 \mathrm{~L} \mathrm{~min}^{-1}$ and $8 \mathrm{~L} \mathrm{~min}^{-1}$ in steps of $2 \mathrm{Lmin}^{-1}$. It was observed that the influence on the migration times and peak intensity was not significant. A flow rate $4 \mathrm{Lmin}^{-1}$ was selected as it falls in the range recommended by the manufacturer for a good stability of the spray at the sheath liquid flow rate chosen. Drying gas temperature was tested gradually from $50{ }^{\circ} \mathrm{C}$ to $300{ }^{\circ} \mathrm{C}$. The best signal was obtained with a drying gas temperature of $300^{\circ} \mathrm{C}$.

Under these conditions, the separation and identification of the fourteen cationic dyes was achieved in $10 \mathrm{~min}$. The extracted ion electropherograms (EIE) obtained with the cationic dyes under the optimum conditions are shown in Fig. 4a. 
Table 2

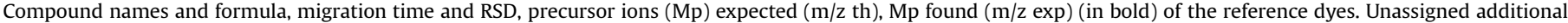

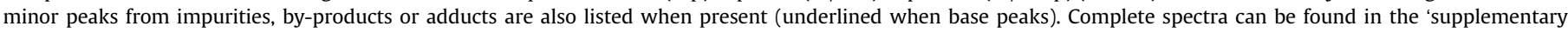
material' file.

\begin{tabular}{|c|c|c|c|c|c|c|c|}
\hline & Formula & $\begin{array}{l}\text { Migrati } \\
\text { (min) }\end{array}$ & $\begin{array}{l}\text { RSD \% } \\
(n=9)\end{array}$ & $\begin{array}{l}\mathrm{Mr} \\
\left(\mathrm{g} \mathrm{mol}^{-1}\right)\end{array}$ & $\begin{array}{l}\text { Precursor ion(s) formula (Mp) } \\
\text { (unascertained } \\
\text { formulas in italics) }\end{array}$ & $\begin{array}{l}\text { Precursor ion(s) (Mp) } \\
\mathrm{m} / \mathrm{z} \text { th}^{\mathrm{a}}\end{array}$ & $\begin{array}{l}\text { Precursor ion(s) (Mp) (+ minor peaks) } \\
\mathrm{m} / \mathrm{z} \exp \end{array}$ \\
\hline \multicolumn{8}{|c|}{ CATIONIC DYES } \\
\hline TT & $\left(\mathrm{C}_{17} \mathrm{H}_{19} \mathrm{~N}_{2} \mathrm{~S}\right)^{+}, \mathrm{Cl}^{-}$ & 5.09 & 1.76 & 318.87 & {$[\mathrm{M}-\mathrm{Cl}]^{+}$} & 283.13 & 282.9, 226.7, 321.0 \\
\hline FB & $\left(\mathrm{C}_{23} \mathrm{H}_{24} \mathrm{~N}_{2} \mathrm{Cl}\right)^{+}, \mathrm{Cl}^{-}$ & 5.18 & 2.23 & 399.36 & {$[\mathrm{M}-\mathrm{Cl}]^{+}$} & 363.16 & 363.1 \\
\hline $\mathrm{AO}$ & $\mathrm{C}_{17} \mathrm{H}_{21} \mathrm{~N}_{3}, \mathrm{HCl}$ & 5.21 & 1.80 & 303.84 & {$[\mathrm{MH}]^{+}$} & 268.18 & 268.0, 212.6 \\
\hline BG & $\left(\mathrm{C}_{27} \mathrm{H}_{33} \mathrm{~N}_{2}\right)^{+}, \mathrm{HSO}_{4}^{-}$ & 5.29 & 3.78 & 482.65 & {$[\mathrm{M}-\mathrm{HSO} 4]^{+}$} & 385.26 & 385.2, 289.8, 450.0 \\
\hline CV & $\left(\mathrm{C}_{25} \mathrm{H}_{30} \mathrm{~N}_{3}\right)^{+}, \mathrm{Cl}^{-}$ & 5.31 & 5.61 & 407.99 & {$[\mathrm{M}-\mathrm{Cl}]^{+}$} & 372.2 & 372.1 \\
\hline RH6G & $\left(\mathrm{C}_{28} \mathrm{H}_{31} \mathrm{~N}_{2} \mathrm{O}_{3}\right)^{+}, \mathrm{Cl}^{-}$ & 5.40 & 1.21 & 479.02 & {$[\mathrm{M}-\mathrm{Cl}]^{+}$} & 443.23 & 443.1, 331.8, 373.0, 462.7 \\
\hline AG & $\mathrm{C}_{17} \mathrm{H}_{21} \mathrm{~N}_{3}, \mathrm{HCl}$ & 5.42 & 2.91 & 303.83 & {$[\mathrm{MH}]^{+}$} & 268.18 & 268.0, 217.7 \\
\hline VBR & $\left(\mathrm{C}_{29} \mathrm{H}_{32} \mathrm{~N}_{3}\right)^{+}, \mathrm{Cl}^{-}$ & 5.43 & 0.78 & 458.05 & {$[\mathrm{M}-\mathrm{Cl}]^{+}$} & 422.26 & 422.1, 241.9, 330.0, 408.2 \\
\hline EV & $\left(\mathrm{C}_{31} \mathrm{H}_{42} \mathrm{~N}_{3}\right)^{+}, \mathrm{Cl}^{-}$ & 5.59 & 1.01 & 492.15 & {$[\mathrm{M}-\mathrm{Cl}]^{+}$} & 456.34 & 456.3, 368.3, 549.2 \\
\hline VBB & $\left(\mathrm{C}_{33} \mathrm{H}_{32} \mathrm{~N}_{3}\right)^{+}, \mathrm{Cl}^{-}$ & 5.78 & 3.09 & 506.1 & {$[\mathrm{M}-\mathrm{Cl}]^{+}$} & 470.26 & 470.2, 354.8, 378.8, 420.0, 440.9, 456.2, 483.7 \\
\hline MB & $\left(\mathrm{C}_{16} \mathrm{H}_{18} \mathrm{~N}_{3} \mathrm{~S}\right)^{+}, \mathrm{Cl}^{-}$ & 5.52 & 3.15 & 319.85 & {$[\mathrm{M}-\mathrm{Cl}]^{+}$} & 284.12 & 284.0, $227.6,361.1,367.2,377.5,387.0$ \\
\hline BB & $\left(\mathrm{C}_{34} \mathrm{H}_{34} \mathrm{~N}_{3}\right)^{+}, \mathrm{Cl}^{-}$ & 6.05 & 4.47 & 520.11 & {$[\mathrm{M}-\mathrm{Cl}]^{+}$} & 484.28 & 484.2, 207.3, 226.6, 299.0, 391.1, 412.2, 450.8 \\
\hline RHB & $\left(\mathrm{C}_{28} \mathrm{H}_{31} \mathrm{~N}_{2} \mathrm{O}_{3}\right)^{+}, \mathrm{Cl}^{-}$ & 6.64 & 7.63 & 479.02 & {$[\mathrm{M}-\mathrm{Cl}]^{+}$} & 443.23 & 443.1, 315.1, 405.0 \\
\hline CG & $\mathrm{C}_{12} \mathrm{H}_{12} \mathrm{~N}_{4}, \mathrm{HCl}$ & 6.78 & 2.03 & 248.72 & {$[\mathrm{MH}]^{+}$} & 213.11 & 212.9, 114.0, 247.8, 291.0 \\
\hline \multicolumn{8}{|c|}{ ANIONIC DYES } \\
\hline PBVF & $\left(\mathrm{C}_{27} \mathrm{H}_{31} \mathrm{~N}_{2} \mathrm{O}_{6} \mathrm{~S}_{2}\right)^{-}, \mathrm{Na}^{+}$ & 8.36 & 0.81 & 566.68 & {$[\mathrm{M}-\mathrm{Na}]^{-}$} & 543.16 & 543.7 \\
\hline PBV & $\left(\mathrm{C}_{27} \mathrm{H}_{31} \mathrm{~N}_{2} \mathrm{O}_{7} \mathrm{~S}_{2}\right)^{-}, 1 / 2 \mathrm{Ca}^{2+}$ & 9.96 & 0.43 & 579.72 & {$\left[\mathrm{M}-0.5 \mathrm{Ca}^{2+}\right]^{-}$} & 559.16 & 559.5, 581.3, 641.3, 663.3 \\
\hline $\mathrm{CH}$ & $\mathrm{C}_{30} \mathrm{H}_{26} \mathrm{~N}_{4} \mathrm{O}_{8} \mathrm{~S}_{2} \mathrm{Na}_{2}$ & 10.27 & 1.27 & 680.67 & {$[\mathrm{M}-2 \mathrm{Na}]^{2-}$} & 317.06 & 317.3, 469.2 \\
\hline $\mathrm{RB}$ & $\left(\mathrm{C}_{20} \mathrm{H}_{2} \mathrm{Cl}_{4} \mathrm{I}_{4} \mathrm{NaO}_{5}\right)^{-}, \mathrm{Na}^{+}$ & 10.24 & 0.86 & 1017.64 & {$[\mathrm{M}-\mathrm{Na}]^{-}$} & 992.38 & 992.5, 715.2, 765.7, $\underline{800.7}, 892.6$ \\
\hline ERB & $\left(\mathrm{C}_{20} \mathrm{H}_{6} \mathrm{I}_{4} \mathrm{NaO}_{5}\right)^{-}, \mathrm{Na}^{+}$ & 12.38 & 1.53 & 879.87 & {$[\mathrm{M}-\mathrm{Na}]^{-} /\left[\mathrm{Mp}-\mathrm{Na}^{+}+\mathrm{H}^{+}\right]^{-}$} & 856.6 / 834.9 & 856.7 / 834.7, $\underline{662.8}$ \\
\hline EY & $\left(\mathrm{C}_{20} \mathrm{H}_{6} \mathrm{Br}_{4} \mathrm{NaO}_{5}\right)^{-}, \mathrm{Na}^{+}$ & 13.00 & 4.04 & 691.88 & {$[\mathrm{M}-\mathrm{Na}]^{-} /\left[\mathrm{Mp}-\mathrm{Na}^{+}+\mathrm{H}^{+}\right]^{-}$} & $668.68 / 646.8^{\mathrm{b}}$ & $\mathbf{6 6 8 . 8}$ / 646.9, 469.2, 521.1, 551.2, 753.7, 800.0 \\
\hline DII & $\mathrm{C}_{20} \mathrm{H}_{10} \mathrm{I}_{2} \mathrm{O}_{5}$ & 13.16 & 1.22 & 584.1 & {$[\mathrm{M}-\mathrm{H}]^{-} /\left[\mathrm{Mp}-\mathrm{H}^{+}+\mathrm{Na}^{+}\right]^{-}$} & 582.85 / 604.9 & $\mathbf{5 8 3 . 1} / \mathbf{6 0 5 . 0}, 537.2,686.9$ \\
\hline ERB2 & $\mathrm{C}_{20} \mathrm{H}_{8} \mathrm{I}_{4} \mathrm{O}_{5}$ & 13.21 & 2.47 & 835.9 & {$[\mathrm{M}-\mathrm{H}]^{-}$} & 834.9 & 834.7, $\underline{662.8}, 689.0,856.7$ \\
\hline EB & $\mathrm{C}_{20} \mathrm{H}_{6} \mathrm{Br}_{2} \mathrm{~N}_{2} \mathrm{Na}_{2} \mathrm{O}_{9}$ & 13.41 & 3.26 & 624.08 & {$[\mathrm{M}-\mathrm{Na}]^{-} /\left[\mathrm{Mp}-\mathrm{Na}^{+}+\mathrm{H}^{+}\right]^{-}$} & $\begin{array}{l}598.74 / 576.84^{\mathrm{c}} \\
600.74 / 578.84^{\mathrm{d}}\end{array}$ & $\mathbf{6 0 1 . 1} / \overline{\mathbf{5 7 9 . 1}}^{\mathrm{d}}, 501.6,680.8,703.4,762.2$ \\
\hline
\end{tabular}

\footnotetext{
a The masses of the molecular and pseudo-molecular ions were calculated based on the exact masses of the lighter isotopes

${ }^{\mathrm{b}}$ Most abundant isotopic combination: $2{ }^{79} \mathrm{Br}$ and $2{ }^{81} \mathrm{Br}$

c Combination with $2{ }^{79} \mathrm{Br}$

${ }^{\mathrm{d}}$ Combination with $1{ }^{79} \mathrm{Br}$ and $1{ }^{81} \mathrm{Br}$
}

The MS and $\mathrm{MS}^{2}$ spectra of each reference dye can be found in the 'supplementary material' file. Table 2 lists the theoretical precursor ions for each dye $(\mathrm{m} / \mathrm{z}$ th) and the experimental ones ( $\mathrm{m} / \mathrm{z}$ exp) as well as minor peaks, which could not be assigned to a specific compound. They likely indicate the presence of degradation by-products or impurities as the dyes are not $100 \%$ pure.

The $\mathrm{MS}^{2}$ daughter ions for the cationic dyes with corresponding proposed fragments or fragment losses, when attributed, are gathered in Table 3. The precursor ions were always identified and most daughter ions could be assigned to specific fragments. Fragment structures or fragment losses could be proposed for all the $\mathrm{MS}^{2}$ base peaks of the cationic dyes except in the case of $\mathrm{FB}$ $(\mathrm{m} / \mathrm{z} 226.7)$. While some of the fragmentations were straightforward (e.g. loss of functional groups or fragments), others were more difficult to assign due to a difference of 1 , and sometimes 2 amu with the possible obvious fragments. Transfers of hydrogen atoms with competition between hydride and proton abstractions would explain some of the fragments found, as tentatively proposed in Table 3. In fact, hydride abstraction has been reported to occur with an ESI interface in positive ion mode on related molecular structures (dihydropyridines and pyrimidines) [33,34]. An explanation for these hydrogen transfers would be high collision energy for the $\mathrm{MS}^{2}$, which could perhaps be avoided by working at lower energies.

The precursor ion was actually sufficient for the identification of the cationic dyes, except for differentiating between RH6G and RHB, which both had $\mathrm{m} / \mathrm{z} 443.1$, and additionally migrated at neighbouring $t_{\mathrm{m}}$ (less than $1 \mathrm{~min}$ difference). Fragmentation in $\mathrm{MS}^{2}$ was thus necessary for their discrimination. For RH6G, a daughter ion $\mathrm{m} / \mathrm{z}$ 415.1 was obtained (no assignment found) and for RHB, two daughter ions were detected at $\mathrm{m} / \mathrm{z} 399.1$ (no assignment found) and $\mathrm{m} / \mathrm{z} 413.1$ (possibly the loss of an ethyl group and addition on the fragment ion of $\mathrm{H}^{+}$). Despite the fact that with $\mathrm{CE}$ separation beforehand $\mathrm{MS}^{2}$ was not essential for identification purposes, it was carried out nevertheless since in real sample matrices, the complexity of the spectra can hinder the identification of peaks, in which case fragments can be useful for confirmation.

\subsubsection{CE-ESI-MS(-) for anionic dyes}

The same stepwise procedure was performed to optimise the method in negative ion mode for the characterisation of the anionic dyes. From methanol, ethanol and 2-propanol in 1:1 mixture with water, 2-propanol allowed for the best sensitivity, the best proportion indeed being $1: 1$ (tested range 1:3,1:1, 3:1). The addition of acid did not improve the signal, the natural charge of the dyes was sufficient for a good ionisation output. Changing the flow rate of the sheath liquid in the range $200 \mu \mathrm{L} \mathrm{h}^{-1}$ to $400 \mu \mathrm{Lh}^{-1}$ showed that $400 \mu \mathrm{L} \mathrm{h}^{-1}$ provided the best peak area and peak height, with a good spray stability. The optimal pressure for the nebulising gas was 7 psi (tested range 5-9 psi). The drying gas flow rate chosen was $4 \mathrm{~L} \mathrm{~min}^{-1}$ (range tested $2 \mathrm{Lmin}^{-1}$ to $8 \mathrm{Lmin}^{-1}$ ), and the drying gas temperature was fixed to $300{ }^{\circ} \mathrm{C}$. This method enabled the separation and identification of the nine anionic dyes within 20 min.

In Fig. 4b the EIE obtained for all the anionic dyes under the optimised conditions are presented. Table 2 lists the precursor ions and other peaks on the spectra assumed to be due to impurities or degradation by-products which could not be assigned. These were mostly minor, although, inexplicably, major in two instances $(\mathrm{m} / \mathrm{z}$ 800.7 for $\mathrm{RB}$ and $\mathrm{m} / \mathrm{z} 662.8$ for ERB and ERB2). Each dye showed a characteristic $\mathrm{m} / \mathrm{z}$, which was identified in all cases. For ERB, EY and $\mathrm{EB}$, two major peaks were found, corresponding to the loss of one and two sodium atoms, respectively (MS spectra can be found in the 
Table 3

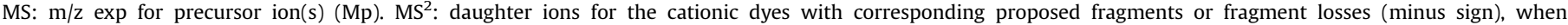

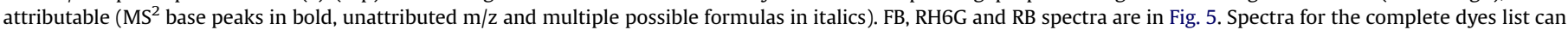
be found in the 'supplementary material' file.

\begin{tabular}{|c|c|c|c|c|}
\hline Dye & $\mathrm{Mp}$ & $\mathrm{MS}^{2}$ ions & & \\
\hline $\mathrm{TT}$ & 282.9 & 267.9 & 161.8 & 120.0 \\
\hline
\end{tabular}

(-) $\mathrm{CH}_{3}$

$(-)$

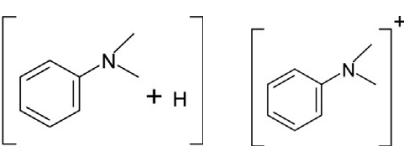

\begin{tabular}{lll}
\hline FB & 363.1 & 327.1 \\
\hline & & $(-) \mathrm{HCl}$ \\
AO & 268.0 & $\begin{array}{l}\mathbf{2 5 3 . 0} \\
(-) \mathrm{CH}_{3}\end{array}$
\end{tabular}

$(-)$

\section{7}

$146.9+122.0$

$122.0 \quad 106.9$

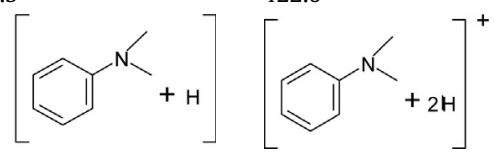

$\left[\begin{array}{r}\mathrm{NCH}_{3} \\ +2 \mathrm{H}\end{array}\right]^{+}$

\begin{tabular}{llll}
\hline BG & 385.2 & 355.2 & 341.2 \\
$(-)\left[\mathrm{C}_{2} \mathrm{H}_{5}+\mathrm{H}\right]$ & $(-)\left[\mathrm{N}\left(\mathrm{C}_{2} \mathrm{H}_{5}\right)+\mathrm{H}\right]$ &
\end{tabular}

\begin{tabular}{llll}
\hline $\mathrm{CV}$ & 372.1 & $\begin{array}{l}\mathbf{3 5 6 . 1} \\
(-)\left[\mathrm{CH}_{3}+\mathrm{H}\right]\end{array}$ & $\begin{array}{l}328.1 \\
(-) \mathrm{N}\left(\mathrm{CH}_{3}\right)_{2}\end{array}$
\end{tabular}

$(-)$

$250.9 \quad 236.1$

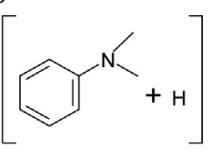

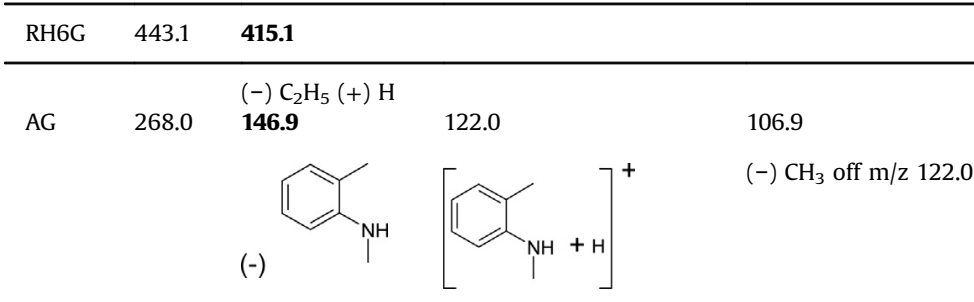

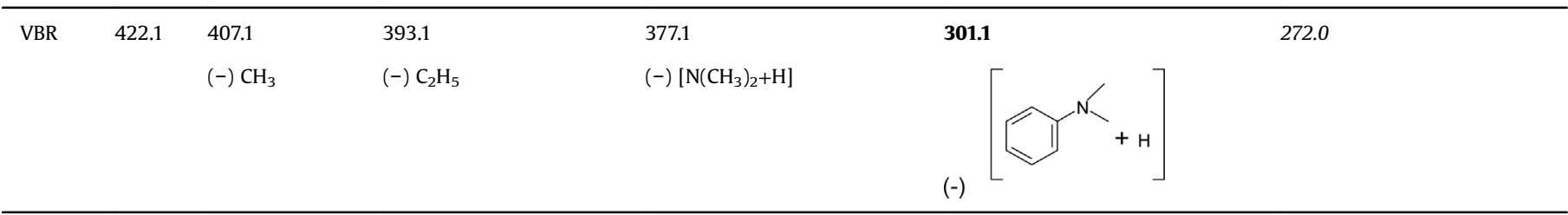

\begin{tabular}{|c|c|c|c|}
\hline EV & 456.3 & $\begin{array}{l}427.2 \\
(-) \mathrm{C}_{2} \mathrm{H}_{5}\end{array}$ & $\begin{array}{l}412.2 \\
(-) \mathrm{CH}_{3} \text { off } \mathrm{m} / \mathrm{z} 427.2 \\
\text { or } \\
(-)\left[\mathrm{N}\left(\mathrm{C}_{2} \mathrm{H}_{5}\right)+\mathrm{H}\right]\end{array}$ \\
\hline
\end{tabular}

\begin{tabular}{|c|c|c|c|c|c|c|}
\hline \multirow[t]{2}{*}{ VBB } & 470.2 & 455.1 & 378.1 & 349.1 & 334.1 & 306.1 \\
\hline & & $(-) \mathrm{CH}_{3}$ & & & (-) $\mathrm{CH}_{3}$ off $\mathrm{m} / \mathrm{z} 349.1$ & (-) $\left[\mathrm{N}\left(\mathrm{CH}_{3}\right)_{2}\right.$ off $\left.\mathrm{m} / \mathrm{z} 349.1\right]+\mathrm{H}$ \\
\hline
\end{tabular}

(-) $\left[\mathrm{N}-\mathrm{CH}_{3}\right.$ off $\left.\mathrm{m} / \mathrm{z} 334.1\right]+\mathrm{H}$

\begin{tabular}{|c|c|c|c|c|c|}
\hline MB & 284.0 & 269.0 & 252.2 & 241.0 & 235.8 \\
\hline BB & 484.2 & $\begin{array}{l}(-) \mathrm{CH}_{3} \\
\mathbf{4 6 9 . 1}\end{array}$ & 363.1 & $\begin{array}{l}(-)\left[\mathrm{N}\left(\mathrm{CH}_{3}\right)_{2}\right](+) \mathrm{H} \\
347.2 / 348.1 / 349.0\end{array}$ & $251.0 / 252.0 / 253.0$ \\
\hline
\end{tabular}


Table 3 (continued)

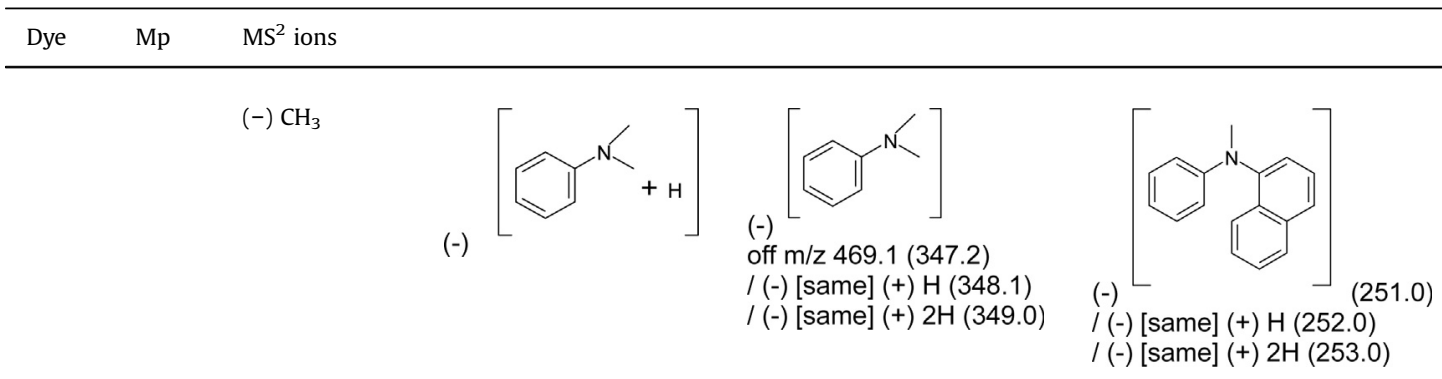

\begin{tabular}{llll}
\hline RHB & 443.1 & $\begin{array}{l}413.1 \\
(-)\left[\mathrm{C}_{2} \mathrm{H}_{5}+\mathrm{H}\right]\end{array}$ & $\begin{array}{l}\mathbf{3 9 9 . 1} \\
(-) \mathrm{CO}_{2}\end{array}$ \\
CG & 212.9 & $\begin{array}{l}195.8 \\
(-) \mathrm{NH}_{3}\end{array}$ & 157.7 \\
& &
\end{tabular}

140.8

120.9

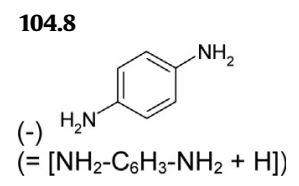

'supplementary material' file). In the case of DII two major peaks were also present, the second peak corresponding to the sodium adduct. The acquisition of the MS spectra resulted sufficient for identification. At any rate, the sensitivity obtained with the anionic dyes being one to two orders of magnitude lower than with cationic dyes, $\mathrm{MS}^{2}$ could not be performed most of the time [32].

\subsection{Identification of the dyes in the Filmcolor photograph}

The sample taken from the Filmcolor was analysed using the CE-ESI-MS methodology developed, with two consecutive injections in positive and negative ion mode. The identification was carried out by comparing $t_{\mathrm{m}}$ and spectra (MS and $\mathrm{MS}^{2}$ ) with those of the reference dyes analysed earlier. MS and $\mathrm{MS}^{2}$ spectra were very complex. A few representative spectra are shown in Fig. 5, the other ones can be found in the 'supplementary material' file.

Four cationic dyes were identified with certainty in positive ion mode: FB (m/z 362.8, MS²: 226.8), BG (m/z 385.0, MS²: $\mathrm{m} / \mathrm{z} 355.3$ and $\mathrm{m} / \mathrm{z}$ 341.1), RH6G (m/z 443.2, $\left.\mathrm{MS}^{2}: \mathrm{m} / \mathrm{z} 415.1\right)$, and MB $(\mathrm{m} / \mathrm{z}$ 284.0, $\mathrm{MS}^{2}: \mathrm{m} / \mathrm{z}$ 268.0). Additionally, two more dyes can be proposed as possibly present as traces: CG (m/z 211.9, MS ${ }^{2}: \mathrm{m} / \mathrm{z}$ 104.9) and $\mathrm{CV}\left(\mathrm{m} / \mathrm{z}\right.$ 372.2, $\left.\mathrm{MS}^{2}: \mathrm{m} / \mathrm{z} 356.0\right)$. Attribution remains cautious for the latter because the intensity of the peak of the MS ${ }^{2}$ fragment ion was very low for CG, and for CV the second $\mathrm{MS}^{2}$ fragment ion expecred ( $\mathrm{m} / \mathrm{z} 250.9)$ was absent. Noteworthy is the presence of the minor unassigned peaks also observed on the reference dyes $\mathrm{MS}^{2}$ spectra at m/z 121.0 and $\mathrm{m} / \mathrm{z} 141.0$ for CG and at $\mathrm{m} / \mathrm{z} 236.8$ for $\mathrm{CV}$.

The following anionic dyes were identified with confidence: RB ( $\mathrm{m} / \mathrm{z}$ 992.5), DII ( $\mathrm{m} / \mathrm{z} 583.3$ and $\mathrm{m} / \mathrm{z}$ 605.9) and ERB (m/z 834.9 and $\mathrm{m} / \mathrm{z}$ 856.4). PBVF (m/z 543.5) and PBV ( $\mathrm{m} / \mathrm{z} 559.6)$ were in our opinion most likely present as traces, and the very low intensity of the peaks required caution in their attribution. As observed for the reference dyes, the range of intensity of the peaks for the anionic dyes was at least one order of magnitude lower than for the cationic dyes. Also noteworthy is the fact that $t_{\mathrm{m}}$ varied slightly compared to $t_{\mathrm{m}}$ for the reference dyes. This was due to the fact that the latter were injected individually or by groups of three, while the Filmcolor sample seemingly contained at least ten dyes. The variation in $t_{\mathrm{m}}$ can also be attributed to sample matrix effect: in the Filmcolor sample organic compounds other than dyes could still be present despite the filtration, thus complicating the separation and possibly modifying the migration properties.

With these results, the following hypothesis can be presented regarding the dyes composition of the Filmcolor: RH6G, RB, DII and ERB (and possibly trace amounts of CG) as red/orange dyes, FB, $\mathrm{MB}$ (and possibly trace amounts of $\mathrm{CV}, \mathrm{PBVF}, \mathrm{PBV}$ ) as blue/violet dyes, and BG as green dye.

Although it is difficult to do a fair comparison due to the fast evolution of the techniques in a couple of decades, previous work on the very same Filmcolor artefact using HPLC-PDA allowed identifying only five dyes: RH6G and Tartrazine (CI. 19140) for the red/orange, PBV and CV for the blue/violet and BG for the green $[26,35]$. Our results thus partly confirmed and enhanced the knowledge of the dyes in the Filmcolor photograph, as six cationic and five anionic dyes were identified, among which seven fully ascertained. The list could even be extended considering that the array of dyes available at the time of production of the Filmcolor expanded beyond the range of those used as references in this work. This diversity of dyes in a single artefact is remarkable. It is unlikely that a starch grain would be dyed with different dyes of the same colour. A common explanation would be that mixtures of dyes could have been used to achieve a subtle colour rendering. Another hypothesis is that different batches of starch of the same colour, but dyed with colourants of different chemical composition at different moments in time, could have been mixed, simply for practical reasons. This would explain that some dyes were indeed present in trace amounts in the sample, which would also explain some of the minor peaks. Also, as mentioned earlier, many synthetic dyes are not $100 \%$ pure and by-products can be formed during the synthesis, which would also add to the intricacy of the analyses.

Using the CE-PDA method on the Filmcolor sample no peak emerged from the background noise, probably because the sample was too dilute for PDA detection. Re-concentration was anyhow not possible due to the very small initial sample volume $(25 \mu \mathrm{l})$ Hence, CE-ESI-MS proved far superior over CE-PDA for the identification of synthetic dyes in a real artefact.

\section{Conclusion}

The methods proposed in this study allowed the separation and identification of fourteen cationic dyes and nine anionic dyes, which can be found in early colour photographic artefacts such as the autochrome Lumière and the Filmcolor.

The CE-PDA method developed is, as far as we know, the first method to enable the analysis of such a large panel of dyes of opposite charge in a single, simple and short analysis (15 min). The sensitivity was not sufficient in the difficult case of the Filmcolor 

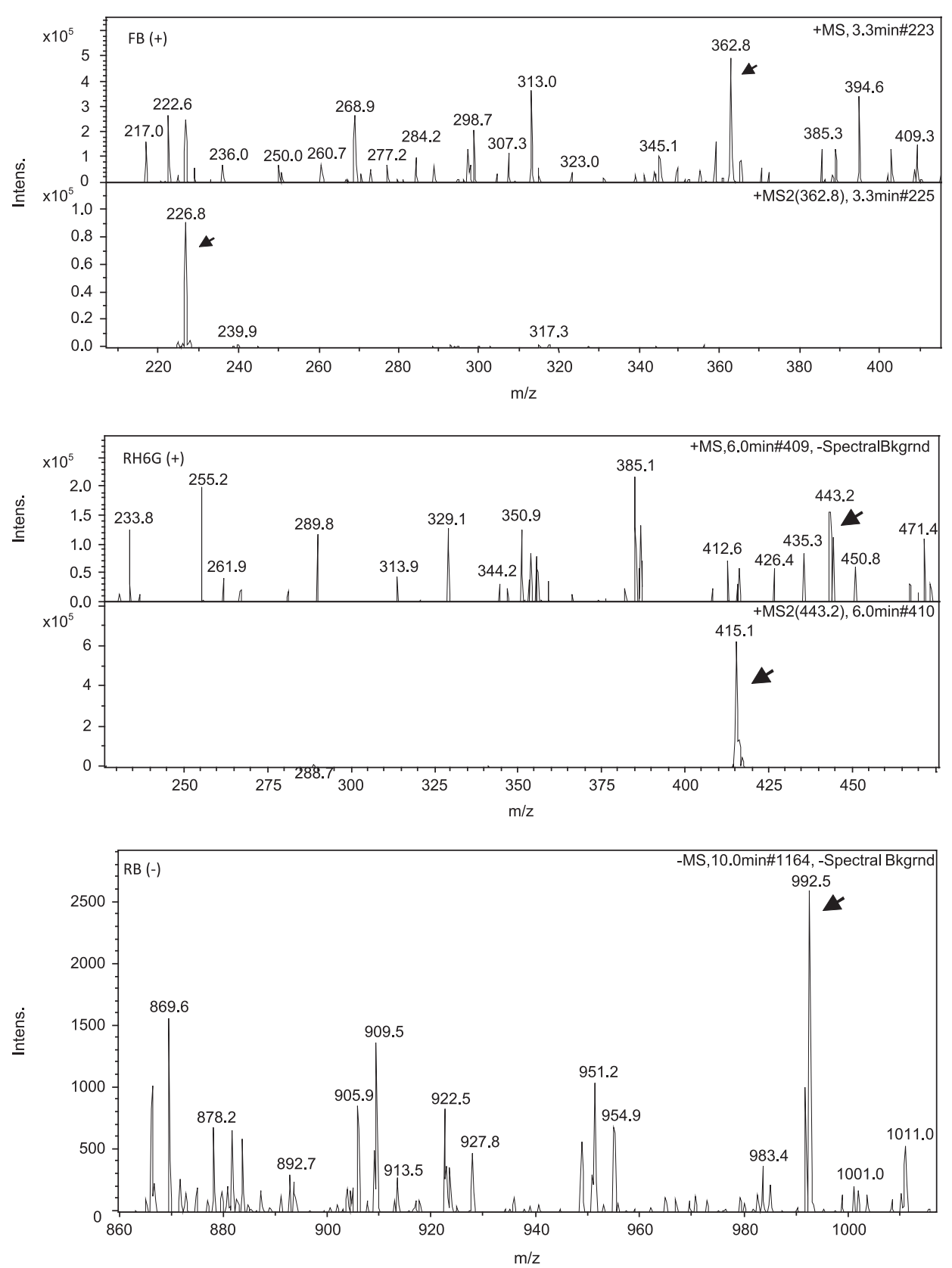

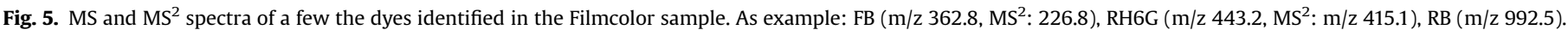
Complete spectra can be found in the 'supplementary material' file.

sample. For challenging applications, the method can thus be proposed as a first identification and screening method to quickly determine which types of dyes are present in very dilute and complex mixtures before applying the more dedicated CE-ESI-MS methodology.

The CE-ESI-MS methodology is straightforward, fast and, as the CE-PDA method, involves no tedious sample pretreatment. The advantage of MS detection lies in the simultaneous determination of all the dyes as the value $\mathrm{m} / \mathrm{z}$ of the molecular or pseudo-molecular ions, as well as that of the $\mathrm{MS}^{2}$ ions, helped in discriminating and identifying compounds even when they showed very close migration times. Furthermore, the CE-ESI-MS methodology has much greater sensitivity than CE-PDA and permits a partial structure elucidation of the dyes. Thanks to the miniaturised sampling, CE-ESI-MS can be applied to small samples such as those originating from valuable cultural heritage artefacts. In this work, it was successfully applied to the historic sample chosen. It has to be noted however that, despite previous cleaning, the Filmcolor sample remained complex and did not allow as good a separation as the reference dyes. This was expected as it is a recurrent challenging problem when analysing the often complex sample matrices originating from historic artefacts. Further improvement of the separation conditions and MS parameters for the detection of cationic and anionic dyes is envisaged to possibly help extend the identifications in the case of complex mixtures and/or very dilute samples. Nevertheless numerous dyes could be identified in the Filmcolor, confirming the analyses carried out by previous researchers, and adding new ones to the list, never identified before, thus enhancing knowledge of the composition of these early photographs. In that respect, caution is advised for some of the identifications proposed in the case of the presence of dyes as traces. On the historic level, it appears likely from this research that dyes could be mixed together to obtain subtle hues or that batches of starch dyed with different dyes of the same colour could have been originally mixed by the manufacturer, resulting in multi-compound 
mixtures, and thus complex dye composition of the photographs, an element that went unnoticed so far.

\section{Acknowledgements}

This work was carried out at CRCC and was supported by a fellowship from University of Granada allocated to Ana $\mathrm{M}^{\mathrm{a}}$ López Montes. Bruker Daltonics is gratefully acknowledged for technical help.

\section{Appendix A. Supporting information}

Supplementary data associated with this article can be found in the online version at http://dx.doi.org/10.1016/j.talanta.2013.04.020.

\section{References}

[1] International Symposium: the Stability and Preservation of Photographic Images, The Public Archives of Canada, Ottawa, Ontario, Society of Photographic Scientists and Engineers, Springfield, VA., August 29-September 1, 1982, 50 p.

[2] B. Lavédrine, J.-P. Gandolfo. Collection archéologie et histoire de l'art no. 29, L'Autochrome Lumière, secrets d'atelier et défis industriels, CTHS, Paris, 2009, $391 \mathrm{p}$.

[3] B. Lavédrine, J.-P. Gandolfo. Topics in photographic preservation, 5, Photographic Materials Group of the American Institute for Conservation of Historic and Artistic Works, Washington, 1993, pp. 138-145.

[4] P. Roberts., in: A. Deutsch (Ed.), A Century of Colour Photography: from the Autochrome to the Digital Age, Carlton publishing group, London, 2007, p. 256.

[5] B. Lavédrine, C. von Waldthausen, L. Gann in: C. McCabe (Ed.). Coatings on Photographs: Materials, Techniques and Conservation, Photographic Materials Group of the American Institute for Conservation of Historic and Artistic Works, Washington, 2005, pp. 132-139.

[6] A. Sayewetz, Revue générale des matières colorantes, août1939 (1939) 1.

[7] S. Suzuki, M. Shirao, M. Aizawa, H. Nakazawa, K. Sasa, H. Sasagawa., J. Chromatogr. A 680 (2) (1994) 541-548.

[8] H. Liu, T. Zhu, Y. Zhang, S. Qi, A. Huang, Y. Sun., J. Chromatogr. A 718 (1995) $448-453$.
[9] M. Masár, D. Kaniansky, V. Madajová., J. Chromatogr. A 724 (1996) 327-336.

[10] C.T. Costa, D. Horton, S.A. Margolis, J. Chromatogr. A 881 (2000) 403-410.

[11] M. Pérez-Urquiza, J.L. Beltrán., J. Chromatogr. A 898 (2000) 271-275.

[12] M. Pérez-Urquiza, J.L. Beltrán., J. Chromatogr. A 917 (2001) 331-336.

[13] H.Y. Huang, Y.C. Chih, Y.C. Chen., J. Chromatogr. A 959 (2002) 317-325.

[14] H.-Y. Huang, C.-W. Chiu, S.-L. Sue, C.-F. Cheng., J. Chromatogr. A 995 (2003) 29-36.

[15] D. Calvo, R. Sáenz-López, P. Fernández-Zurbano, M.T. Tena., Anal. Chim. Acta $524(1-2)$ (2004) 207-213.

[16] M. Ryvolová, P. Táborsky, P. Vrábel, P. Krásenský, J. Preisler., J. Chromatogr. A 1141 (2007) 206-211.

17] E. Mejía, Y. Ding, M.F. Mora, C.D. García., Food. Chem. 102 (2007) 1027-1033

[18] L. Farry, D.A. Oxspring, W.F. Smyth, R. Marchant., Anal. Chim. Acta 349 (1997) 221-229.

[19] H. Sirén, R. Sulkava., J. Chromatogr. A 717 (1995) 149-155.

[20] J.A. Zlotnick, F.P. Smith., Forensic Sci. Int. 92 (1998) 269-280.

[21] C. Vogt, J. Vogt, A. Becker, E. Rohde., J. Chromatogr. A 781 (1997) 391-405.

[22] K.-L. Kuo, H.-Y. Huang, Y.-Z. Hsieh., Chromatographia 47 (5/6) (1998) 249-256.

[23] A.A. Peláez-Cid, S. Blasco-Sancho, F.M. Matysik, Talanta 75 (2008) 1362-1368.

[24] T. Poiger, S.D. Richardson, G.L. Baughman., J. Chromatogr. A 886 (2000) 259-270.

[25] X. Zhao, Y. Lu, D.R. Phillips, H.M. Hwang, I.R. Hardin., J. Chromatogr. A 1159 (2007) 217-224.

[26] B. Lavédrine. Les Autochromes, Approche Historique Et Technologique Du Procédé. Etude des Problémes Liés A Sa Conservation, Ph.D. Thesis, Université de Paris I-Panthéon-Sorbonne, Paris, 1992, 211 p.

[27] M. Mokkadem, P. Gareil, J.-E. Belgaied, A. Varenne, Electrophoresis 29 (2008) 1957-1964.

[28] A.R. Fakhari, M.C. Breadmore, M. Macka, P.R. Haddad., Anal. Chim. Acta 580 (2006) 188-193.

[29] X. Zhao, Y. Lu, D.R. Phillips, H.-M. Hwang, I.R. Hardin., J. Chromatogr. A 1159 (2007) 217-224.

[30] P. Hommerson, A.M. Khan, G.J. de Jong, G.W. Somsen, Mass Spectrom. Rev. 30 (60) (2011) 1096-1120.

31] G.K.E J. Scriba., J. Chromatogr. A 1159 (2007) 28-41.

[32] N.B. Cech, C.G. Enke., Mass Spectrom. Rev. 20 (2001) 362-387.

[33] Y. Chai, H. Sun, J. Wan, Y. Pan, C. Sun, Analyst 136 (2011) 4667-4669.

[34] L.R. Orelli, M.B. García, I.A. Perillo, L. Tonidandel, P. Traldi., Rapid Commun. Mass Spectrom. 20 (5) (2006) 823-828.

[35] B. Lavédrine, J.-P. Gandolfo, J.-M. Susbielles. Preprints of the International Council of Museums Committee for Conservation 10th Triennial Meeting 1993, pp. 275-280. 